\title{
ECONOMIC IMPLICATION OF WEEKLY MARKET PARTICIPATION: A CASE STUDY OF FARMERS CUM SELLERS IN GARO HILLS OF MEGHALAYA
}

\author{
Dr. Sunildro L.S. Akoijam
}

\begin{abstract}
The purpose of this paper is to examine the economic impacts of the weekly market participation by farmers cum sellers in their livelihood. Data were collected from farmers cum sellers who participated in the weekly markets located in Garo Hills region of Meghalaya state in India. Altogether 530 farmers (5 farmers each from 106 weekly markets) participated in the interview process through semi structured schedule for collecting the data. ANOVA and Chi Square test were used to analyse the data. Findings indicate that farmers participating in the weekly markets by selling their agricultural products; are able to earn a sustainable income for their livelihood. With their continuous participation in the weekly markets, their economic status of their family is also improved.
\end{abstract}

Key words: Economic impact, farmers, income, rural areas, weekly market.

\section{Introduction}

Weekly markets play a crucial role in the socio economic development of rural people in India as they are the centers of compilation and distribution of rural produces in the villages. The agricultural produce in rural India is mostly collected, distributed and resold through weekly or periodic markets which are less controlled and regulated by the State Government. Weekly markets are mostly located in the inaccessible areas of villages being disorganised and transacting business in an unsystematic manner. They are not just the centers for transactions of goods and services but they also serve as the platform for the rural people to meet and socialize among themselves and discuss wide array of issues of common interest particularly social, political and economic situations existing in the area. The level of perception about the importance of weekly market varies from one level of participation to another as there is difference in the involvement in the marketing of weekly markets by various participants. The weekly market evade from direct competition with neighbouring markets and rather provide better opportunities for sellers and consumers who participate in their nearby weekly markets. Some of the major challenges that are pertinent in rural markets are the scattered nature of rural market, smaller size, poor connectivity, remoteness \& 
heterogeneity, numerous languages $\&$ dialects, cultural diversities, inadequate banking facilities, spurious products, seasonal demand etc. which make it difficult to tap the rural market. It is evident with the failure of many markets in rural India. Sathyanarayana (2011) asserted that success of rural markets has been due to luck in many cases. Hence the marketers need to characteristics and nature of rural markets in terms of socio-economic variables as well as consumer behavior of rural people. Weekly markets are meant to support and promote trading for rural people. This system helps in up gradation of villages into small towns with increased rural settlements.

The existence of weekly markets in Garo Hills of Meghalaya state in India can be traced during pre colonial period since 10th AD (Kar, 2018). The agricultural crops were through Jhum Cultivation by Garos and main crops were chilly, jute, mustard and cotton. These weekly markets were concentrated in the rural areas and they were important for social and economic development of those farmers (Kar, 2013). These markets served as a place for exchange for essential commodities like cloths, iron tools $\&$ implements, as well as other items with produces of the farmers. These markets are really suitable for Garo Hills region which has rural population of $88.41 \%$ which is significantly higher even than state average of $79.93 \%$ (2011 census). Rice and Maize are the major traditional cash crops of Garo Hills. The livelihood of almost three fourths of the people in Garo Hills is directly or indirectly linked with agriculture. Informal rural markets form an important part of the entire market system in Garo Hills. Most of the consumers Garo Hills also rely on the weekly market for vegetables and other basics commodities because of various reasons which include the vegetables and fruits are fresh, it reduces the purchasing time of consumers and it helps in making social balance through interaction of different income groups etc. These markets play a pivotal role in the rural economy and livelihood of thousands of people in the region. But the rural weekly market is difficult to be gauged in spite of its significant role in the lives of people in region. The study is needed to analyse the economic impact of the weekly markets participation on the lives of these farmers in order to assess the sustainability and viability of their future participation.

\section{Review of Literature and hypotheses development}

Afsar (1993) defined periodic markets as those markets which are not held daily but less than week days. These markets are the centers where people from diverse ethnic and cultural background meet, interact and exchange their goods. These markets serve various purposes for different participants mainly socio-economic dimensions. Shinha and Pradhan (2009) also expressed that haats are generally for selling the small quantities of produces by farmers for rural consumers. They form a part of network of market arranged on periodic basis on a specific day in a week. They are generally located at a central place in a rural area specially village beside a road in close proximity to a village. Similarly, Roy \& Basu (2010) also asserted that haats are centers for exchange of essential goods and services in both rural and urban areas across the globe. The haat systems are significant for the development of socio-economic life of 
rural people. These markets deal with low priced products for essential items and they normally lack basic infrastructural amenities (Deka \& Bhagbati, 2010). Purkayastha (2019) in a study on weekly market in Byrnihat in Ri-Bhoi district of Meghalaya aseerted that these markets play an important role in satisfying the needs of indigenous people as well as people rom neighbouring state of Assam. In these markets, local goods as well as goods from neighbouring state are also traded. He also highlighted that the market participants are the sole earners of the family and the market participation plays a crucial role in their economic sustainability of the family and serve as the only means of livelihood. Ikechukwu and Innocent (2019) highlighted that the periodic markets play roles in fostering rural development. The income from these markets helps in the rural income growth that will ultimately boost the nation's economy. The farmers are engaged in rural subsistence agriculture with only little surplus produce which they take to the market for sales. With their participation in the markets, they are able to feed their families and also take care. According to Kio Lawson et al., (2015), rural weekly markets are normally held at specific place and time during which people particularly buyers and sellers interact and exchange commodities. Despite the increased rate of rural urban migration, the rural periodic market continues to enjoy high patronage.

According to Khosravi (1979), the periodic markets act as a venue for socio economic development for villagers in the nearby villages and city dwellers. In these markets, both men and women participate as a means of earning a sustainable income for livelihood. Similarly, Mukherjee (1968) also stated that these kind of markets are located nearby villages or town convenient for all participants particularly buyers and sellers. According to Trobe (2008), the farmer's markets normally provide fresh local organic foods at much cheaper prices directly to consumers and thereby supporting local farmer producers that strengthen the rural economy. Lyson, Gillespie and Hilchey (1995) expressed that the markets promote rural entrepreneurs to produce and provide essential commodities for rural masses. In this way, the rural economy as well the individual economic life of rural people gets enhanced. Kulkarni and Murali (1996) conducted a study on purchasing practices of consumer in weekly market centers at Parbhani. The results revealed that consumers normally purchase groceries, milk, vegetables, snacks and fruits from retail market. Consumers pay by cash and prefer quality food. They further stated that the economic organization of the society depends fundamentally on periodicity and pattern of market centers. According to Sayulu and Reddy (1998), products like groceries and others like milk, vegetables, fruits etc are purchased from weekly markets by majority of rural people. Price of goods is the most influential factor for the consumers and they are mostly paid by cash. Rural consumers are apathetic to their problems mainly due to low purchasing power. Donna Perry (2000) emphasised that small farmers are strengthened with the emergence of rural weekly markets in Senegal. Through weekly markets, community relations among the small farmers and their neighbors as well as kin are strengthened. Farmers continue to benefit from multiplex interactions with one another through weekly markets. Small farmers are augmenting economic security through weekly markets by new modes of 
exchange with one another. Rajagopal and Rao (2001) stated that weekly markets are playing pivotal roles in terms of providing grocery and several daily need commodities which are sold by producer sellers. These markets act as platform for the rural famers to sell their marketable surplus for a means of earning for livelihood. Koli and Bodhale (2006) discussed that agricultural marketing generally include the activities involved in the movement of agricultural produces from the farmers to the ultimate consumer. This marketing is very important in the dynamic and growing agricultural economy. Velayudhan (2007) focused on tradition of haat bazaar which has been continuing since ages and act as a major source of attractions for consumers as well tourists. These markets have been dominant in the rural areas which are participated by different seller selling varieties of commodities. Kashyap and Raut (2006) analysed the market mechanism of haats in terms of community participation in the rural haats. These haats provide platform for community gatherings and showcase the specialties of numerous communities residing nearby.

Wanmali (1987) argued that established regulated markets do not serve the small farmers as is claimed by (Johnsom, 1965, 1970) and the State Governments (Government of Andhra Pradesh, 1970; Government of Bihar, 1971, Government of Karnataka, 1974; Government of Maharastra, 1963). This is because, according to Wanmali, the small farmers transact their business with traders in the haats (periodic markets) which as functional entities, operate in a different geographical space from that of the regulated market. Hay and Smith (1980) observed that periodic markets can beneficial to consumers in terms of the existence of markets, lower prices, a greater range of goods, a greater access to markets and a choice of alternative suppliers. They also further note that periodic marketing may result in a lower frequency of services in time and a narrower choice of suppliers. Scott, E.P. (1972) asserted that periodic markets play significant roles as act as exchange systems to stimulate economic dependence on inter and intra regional trading. This exchange system reduces the economic dependence on the urban centers and also shifts the socio-economic bases of community towards expansion of production and growth. Weekly markets play the role of both commercial as well as social transactions for rural people. The markets serve as the centers for fulfillment of social and economic needs of the rural people (Thakur, R.N., 1997). Das and Chattopadhyay (2015) stated that periodic markets significantly control the livelihood of the sellers and consumers in the rural sector of West Bengal. They also found that periodic markets maintain a meaningful system of economic process.

Khan (2009) highlighted that periodic markets are the most important socioeconomic institutions which play the pivotal role in reshaping the socio economic and cultural structure of rural masses. The study revealed that participants could increase their income level through their participation in these markets. The savings as well as the purchasing power of market participants has increased to some extent due to the increase in their income level. The housing condition of the farmers also has changed to some extent. The educational level of children of the participants is also increased due 
to market participation. The study also found that the health status and their quality of life are changed to some extent. Pawar and Kirulkar (2020) stated that the weekly market is very important for the development of the villages located around weekly market city and village. As a result, the Government Marketing Committee and Local self government have developed the area of the weekly market through well planned and they provided good facilities for the people. Barman and Bhatacherjee (2016) also highlighted that haats in Garo Hills play a significant role in tribal setting for buying and selling of commodities. They concluded that local haat participants play a crucial role in the success of these markets.

From the literature, it is found that weekly/periodic markets play a crucial role in the development of rural areas. Farmers participate in the rural weekly markets as a source of livelihood and most of their families are dependent on these markets. With the participation in the weekly markets, most of the farmers are able to earn a sustainable income for their livelihood. The farmers are able to increase their economic status with continuous participation in these weekly markets. However, the study on economic impact of the weekly markets on farmers cum seller who sell their agricultural produces in the weekly markets for their livelihood is not there. Hence, the study tries to fulfill this gap.

From the literature review, the following hypotheses are formulated:

H1: Average monthly income of farmers is not significantly different among five district of Garo Hills

H2: Family economic status improvement is not significantly different among five district of Garo Hills.

H3: Years of selling commodities in the market has no significant effect on average monthly income from the market.

H4: Years of selling commodities in the market has no significant effect on family economic status improvement of farmers.

H5: Frequency of participation in the market has no significant effect on average monthly income from the market.

H6: Frequency of participation in the market has no significant effect on family's economic status improvement of farmers.

\section{Methodology}

The study is exploratory and conclusive research in nature. The study is conducted only within the five districts of Garo Hills in Meghalaya. The study is confined only to farmers within the Garo Hills who are directly engaged within the weekly market within the region as sellers. Both the first and secondary data are used for the study. The data are collected directly from farmers cum sellers who are engaged in weekly markets in Garo Hills through semi structured schedules. Information and inputs are also taken from various stakeholders including buyers, authorities of GHADC, market committee members and sellers from outside the region including neighbouring state through personal interview. The secondary data include audited records, journals, magazines, 
published and unpublished records of related organizations like District information centre, research studies conducted by different organizations and individuals within the field.

For analyzing the economic impact, the variables used are average monthly income, ability to meet family expenditure, ability to save, business growth, profitability, property expansion and improvement of family economic status. The primary data are collected using random sampling method. The target population for the survey is the farmers cum seller who are engaged directly in weekly market in Garo Hills. There are 148 weekly markets that are operating in Garo Hills (GHADC Report, 2017-18). However out of this, 106 weekly markets are operating in regular basis and all these 106 markets are considered for the study. In order to have a good representation of the population, data are collected from 530 farmers cum seller, 5 farmers each from 106 markets $(5 * 106=530)$.

\section{Table 1}

District wise Number of weekly markets in Garo Hills, Meghalaya

\begin{tabular}{|c|c|c|c|}
\hline SI No. & Name of district & Headquarter & No. of markets \\
\hline 1 & East Garo Hills & Willamnagar & 18 \\
\hline 2 & West Garo Hills & Tura & 72 \\
\hline 3 & North Garo Hills & Resubelpara & 18 \\
\hline 4 & South Garo Hills & Baghmara & 23 \\
\hline 5 & $\begin{array}{c}\text { South West Garo } \\
\text { Hills }\end{array}$ & Ampati & 17 \\
\hline \multicolumn{2}{|c|}{ Total } & $\mathbf{1 4 8}$ \\
\hline
\end{tabular}

Source: Office of the Garo Hills autonomous District Council, Tura, Dept. of Land and Revenue, (2017-2018)

\section{Table 2}

Sample for the study

\begin{tabular}{|l|l|l|l|}
\hline District & Number of markets & Number of respondents & Percentage \\
\hline
\end{tabular}


Towards Excellence: An Indexed, Refereed \& Peer Reviewed Journal of Higher Education / Dr. Sunildro Akoijam / Page 567-583

\begin{tabular}{|l|c|c|c|}
\hline East Garo Hills & 14 & 70 & 13.2 \\
\hline West Garo Hills & 50 & 250 & 47.1 \\
\hline $\begin{array}{l}\text { South West Garo } \\
\text { Hills }\end{array}$ & 15 & 75 & 14.2 \\
\hline North Garo Hills & 15 & 75 & 14.2 \\
\hline South Garo Hills & 12 & 60 & 11.3 \\
\hline Total & $\mathbf{1 0 6}$ & $\mathbf{5 3 0}$ & $\mathbf{1 0 0 . 0}$ \\
\hline
\end{tabular}

Source: Primary data

For the analysis of study, ANOVA is used to check the significant differences in economic variables among five different districts of Garo Hills. Moreover, Chi square test is used to check the economic impact of market participation on the farmer's lives.

\section{Results and discussion}

Most of the farmers (76\%) are selling commodities in the markets above 6 years which indicates that they have been depending on the weekly markets for their livelihood for a long time (table 3 ).

Table 3

Years of selling commodities in the market

\begin{tabular}{|c|c|c|c|c|c|}
\hline \multirow{2}{*}{ District } & \multicolumn{2}{|c|}{ Years of selling commodities in the market } & \multirow{2}{*}{ Total } \\
\cline { 2 - 5 } & $\begin{array}{c}\text { less than a } \\
\text { year }\end{array}$ & $\begin{array}{c}\mathbf{2 - 4} \\
\text { years }\end{array}$ & $\mathbf{4 - 6}$ years & $\begin{array}{c}\text { 6 years \& } \\
\text { above }\end{array}$ & \\
\hline East Garo Hills & 1 & 4 & 9 & 56 & 70 \\
\hline West Garo Hills & 0 & 30 & 55 & 165 & 250 \\
\hline $\begin{array}{c}\text { South West Garo } \\
\text { Hills }\end{array}$ & 0 & 2 & 5 & 68 & 75 \\
\hline North Garo Hills & 0 & 4 & 8 & 63 & 75 \\
\hline South Garo Hills & 0 & 3 & 6 & 51 & 60 \\
\hline Total & $\begin{array}{c}\mathbf{1} \\
\mathbf{( 0 . 2 \% )}\end{array}$ & $\begin{array}{c}\mathbf{4 3} \\
\mathbf{( 8 . 1 \% )}\end{array}$ & $\begin{array}{c}\mathbf{8 3} \\
\mathbf{( 1 5 . 7 \% )}\end{array}$ & $\begin{array}{c}\mathbf{4 0 3} \\
\mathbf{( 7 6 \% )}\end{array}$ & $\begin{array}{c}\mathbf{5 3 0} \\
\mathbf{( 1 0 0 \% )}\end{array}$ \\
\hline
\end{tabular}

Source: field survey

If we see the data district wise also, it is evident that the majority of the farmers in all these districts have been participating in the weekly markets for more than 6 years. This indicates that these farmers in all districts have been dependent on these weekly markets for their livelihood earnings since long time. 
The farmer respondents are participating the weekly market in two modes i.e. throughout the year and seasonally. Most of the farmers $(77.7 \%)$ participate seasonally in the markets as they are selling their seasonal agricultural products which are produced on their own and rest participates throughout the year (table 4).

\section{Table 4}

Frequency of participation in the market

\begin{tabular}{|c|c|c|c|}
\hline \multirow{2}{*}{ District } & \multicolumn{2}{|c|}{ Frequency of participation in the market } & \multirow{2}{*}{ Total } \\
\cline { 2 - 3 } & throughout the year & seasonal & \\
\hline East Garo Hills & 12 & 58 & 70 \\
\hline West Garo Hills & 56 & 194 & 250 \\
\hline South West Garo Hills & 10 & 65 & 75 \\
\hline North Garo Hills & 37 & 38 & 75 \\
\hline South Garo Hills & 3 & 57 & 60 \\
\hline Total & $\mathbf{1 1 8}$ & $\mathbf{4 1 2}$ & $\mathbf{5 3 0}$ \\
& $\mathbf{( 2 2 . 3 \% )}$ & $\mathbf{( 7 7 . 7 \% )}$ & $\mathbf{1 0 0 \% )}$ \\
\hline
\end{tabular}

Source: field survey

If we see the data district wise also, it is evident that the farmers in all these districts participate in the weekly markets seasonally rather than participating throughout the year. These farmers grow seasonal vegetables in their own land and they sell these produces in the weekly markets. As a result, they can't participate in the weekly markets throughout the year.

Every market has economic impacts towards the lives of farmers who participate in the market as sellers. The weekly markets in Garo Hills of Meghalaya also have the similar economic impact. The average monthly income of the farmer from the market differs. $49.6 \%$ of the respondents can earn an average monthly income ranging from Rs. 2000 to Rs. 5000 which is followed by $40.9 \%$ (Rs. 5000 to Rs. 8000 ). It is also evident that $7.2 \%$ of farmers also earn an average monthly income of Rs 8000 and above which is considered to be high among these group of farmers. This indicates that farmers are earning a sustainable income from the participation of weekly markets and it can provide a scope of earning higher monthly income for these farmers.

\section{Table 5}

Average monthly income from the market (in Rs) 
Towards Excellence: An Indexed, Refereed \& Peer Reviewed Journal of Higher Education / Dr. Sunildro Akoijam / Page 567-583

\begin{tabular}{|c|c|c|c|c|c|}
\hline & $\begin{array}{c}\text { less than } \\
\mathbf{2 0 0 0}\end{array}$ & $\mathbf{2 0 0 0 - 5 0 0 0}$ & $\mathbf{5 0 0 0 - 8 0 0 0}$ & $\begin{array}{c}\mathbf{8 0 0 0} \\
\text { above }\end{array}$ & \\
\hline East Garo Hills & 1 & 26 & 39 & 4 & 70 \\
\hline West Garo Hills & 5 & 158 & 78 & 9 & 250 \\
\hline $\begin{array}{c}\text { South West Garo } \\
\text { Hills }\end{array}$ & 4 & 15 & 36 & 20 & 75 \\
\hline North Garo Hills & 1 & 37 & 34 & 3 & 75 \\
\hline South Garo Hills & 1 & 27 & 30 & 2 & 60 \\
\hline Total & $\begin{array}{c}\mathbf{1 2} \\
(\mathbf{2 . 3 \% )}\end{array}$ & $\begin{array}{c}\mathbf{2 6 3} \\
(\mathbf{4 9 . 6 \% )}\end{array}$ & $\begin{array}{c}\mathbf{2 1 7} \\
\mathbf{( 4 0 . 9 \% )}\end{array}$ & $\begin{array}{c}\mathbf{3 8} \\
\mathbf{( 7 . 2 \% )}\end{array}$ & $\begin{array}{c}\mathbf{5 3 0} \\
(\mathbf{1 0 0 \%})\end{array}$ \\
\hline
\end{tabular}

Source: field survey

The farmers are participating in the weekly markets for their sustainable income for livelihood for their family. With their monthly income from the weekly markets, they manage their family expenditure. $70 \%$ of the farmer respondents expressed that they are able to manage their family expenditure with the income from weekly markets. However $30 \%$ of farmers expressed that their incomes are not able to meet the expenditures because of the large number of family size as well as due to various unplanned expenditures throughout the year.

Table 6

Managing family expenditure by farmers

\begin{tabular}{|c|c|c|c|}
\hline \multirow{2}{*}{ District } & \multicolumn{2}{|c|}{ Able to manage your family expenditure } & \multirow{2}{*}{ Total } \\
\cline { 2 - 3 } & Yes & No & \\
\hline East Garo Hills & 50 & 20 & 70 \\
\hline West Garo Hills & 174 & 76 & 250 \\
\hline South West Garo Hills & 46 & 29 & 75 \\
\hline North Garo Hills & 60 & 15 & 75 \\
\hline South Garo Hills & 41 & 19 & 60 \\
\hline Total & $\mathbf{3 7 1}$ & $\mathbf{1 5 9}$ & $\mathbf{5 3 0}$ \\
& $\mathbf{( 7 0 \% )}$ & $\mathbf{( 3 0 \% )}$ & $(\mathbf{1 0 0 \% )}$ \\
\hline
\end{tabular}

Source: field survey

Farmers across the five districts also expressed the similar opinion on their ability to manage family expenditure from the income earned through their participation in the weekly markets (table 6).

From among these 371 farmers, 50.4\% expressed that they can save after day to day expenses from the income (table 7). This savings are used mainly for children education, assets expansion and medical expenses. Most of the farmers (183 out of 188 respondents) used the saving for children education; some of them used for 
assets expansion (45 respondents) and medical expenses (98 respondents). This indicates that these savings are used not only for one purpose but for multiple purposes. Some of the farmers also expressed that they used the savings for all the three purposes. On the other hand $49.6 \%$ respondents opined that they could not save after meeting the family expenditures. They further stated that the increasing expenditure mainly due to the increasing inflation made them unable to save anything.

Table 7

Able to save money by farmers

\begin{tabular}{|c|c|c|c|}
\hline \multirow{2}{*}{ District } & \multicolumn{2}{|c|}{ Able to save money } & \multirow{2}{*}{ Total } \\
\cline { 2 - 3 } & Yes & No & \\
\hline East Garo Hills & 29 & 21 & 50 \\
\hline West Garo Hills & 97 & 76 & 173 \\
\hline South West Garo Hills & 13 & 34 & 47 \\
\hline North Garo Hills & 33 & 28 & 61 \\
\hline South Garo Hills & 16 & 26 & 42 \\
\hline Total & $\mathbf{1 8 8}$ & $\mathbf{1 8 5}$ & $\mathbf{3 7 3}$ \\
& $\mathbf{( 5 0 . 4 \% )}$ & $\mathbf{( 4 9 . 6 \% )}$ & $(\mathbf{1 0 0 \% )}$ \\
\hline
\end{tabular}

Source: field survey

If we see the data district wise, we can see that in two districts; South West Garo Hills and South Garo Hill, the number of famers who could not save anything after meeting expenditure from income are more than who could save (table 7).

The business in the weekly market is growing. It is observed that $89.8 \%$ of the farmers agreed to the statement. They expressed that they have been able to increase the volume of commodities that they sell in the weekly markets due to increased experience in farming of agricultural products from time to time.

\section{Table 8}

\section{Business in the weekly market is growing}

\begin{tabular}{|c|c|c|c|}
\hline \multirow{2}{*}{ District } & \multicolumn{2}{|c|}{ Business in the weekly market is growing } & \multirow{2}{*}{ Total } \\
\cline { 2 - 3 } & Yes & No & \\
\hline East Garo Hills & 65 & 5 & 70 \\
\hline West Garo Hills & 232 & 18 & 250 \\
\hline South West Garo Hills & 63 & 12 & 75 \\
\hline North Garo Hills & 69 & 6 & 75 \\
\hline South Garo Hills & 47 & 13 & 60 \\
\hline
\end{tabular}


Towards Excellence: An Indexed, Refereed \& Peer Reviewed Journal of Higher Education / Dr. Sunildro Akoijam / Page 567-583

\begin{tabular}{|c|c|c|c|}
\hline \multirow{2}{*}{ Total } & 476 & 54 & 530 \\
& $(89.8 \%)$ & $(10.2 \%)$ & $(100 \%)$ \\
\hline
\end{tabular}

Source: field survey

The table 8 also indicates the same pattern of opinion regarding the growth of business in the markets of farmers in all the districts.

$45.8 \%$ of farmers expressed that their business is profitable throughout the year. But $54.2 \%$ does not agree that their business in the weekly market is profitable throughout the year (table 9). They informed that they could not sell even the small volume of commodities on particular days and as a result the commodities being perishable items got wasted that affected the profitability. Moreover during a particular year, their productions were also affected due various reasons including floods in many places that ultimately affected their business and profitability.

Table 9

Farmer's Business profitability during the whole year

\begin{tabular}{|c|c|c|c|}
\hline \multirow{2}{*}{ District } & \multicolumn{2}{|c|}{ Business is profitable during the whole year } & \multirow{2}{*}{ Total } \\
\cline { 2 - 3 } & Yes & No & \\
\hline East Garo Hills & 37 & 33 & 70 \\
\hline West Garo Hills & 119 & 131 & 250 \\
\hline South West Garo Hills & 28 & 47 & 75 \\
\hline North Garo Hills & 46 & 29 & 75 \\
\hline South Garo Hills & 13 & 47 & 60 \\
\hline Total & $\mathbf{2 4 3}$ & $\mathbf{2 8 7}$ & $\mathbf{5 3 0}$ \\
& $\mathbf{( 4 5 . 8 \% )}$ & $\mathbf{( 5 4 . 2 \% )}$ & $(\mathbf{1 0 0 \% )}$ \\
\hline
\end{tabular}

Source: field survey

The district wise data (table 9) indicates that majority of East Garo Hills district farmers agreed that their business is profitable throughout the year which is not in case of other four states.

Due to the limited income and increased expenditure, majority of the farmers (63\%) expressed that they could not expand their properties (table 10). On the other hand, 37\% farmers were able to expand their properties. They bought assets such as television, refrigerator, cycle, bike, scooter, etc. as reported by the farmers from their income.

Table 10

Able to expand your properties

\begin{tabular}{|c|c|c|}
\hline District & Able to expand your properties & Total \\
\hline
\end{tabular}


Towards Excellence: An Indexed, Refereed \& Peer Reviewed Journal of Higher Education / Dr. Sunildro Akoijam / Page 567-583

\begin{tabular}{|c|c|c|c|}
\hline & Yes & No & \\
\hline East Garo Hills & 30 & 40 & 70 \\
\hline West Garo Hills & 96 & 154 & 250 \\
\hline South West Garo Hills & 21 & 54 & 75 \\
\hline North Garo Hills & 29 & 46 & 75 \\
\hline South Garo Hills & 20 & 40 & 60 \\
\hline Total & $\mathbf{1 9 6}$ & $\mathbf{3 3 4}$ & $\mathbf{5 3 0}$ \\
& $\mathbf{( 3 7 \% )}$ & $\mathbf{( 6 3 \% )}$ & $\mathbf{( 1 0 0 \% )}$ \\
\hline
\end{tabular}

Source: field survey

The district wise data also indicates that famers across the districts also have the similar opinion regarding the ability to expand their properties (table 10).

Last but not the least, the farmers expressed that the overall family economic status has improved. $61.9 \%$ of the farmers stated that their family economic status has been improved over the year in the weekly market and $14.2 \%$ famers opined that their economic status of family is improved significantly.

Table 11

Family economic Status improvement

\begin{tabular}{|l|c|c|c|c|c|c|}
\hline & $\begin{array}{c}\text { Significantly } \\
\text { not improved }\end{array}$ & $\begin{array}{c}\text { Not } \\
\text { improved }\end{array}$ & Can't say & Improved & $\begin{array}{c}\text { Significant } \\
\text { ly } \\
\text { improved }\end{array}$ & Total \\
\hline $\begin{array}{l}\text { East Garo } \\
\text { Hills }\end{array}$ & 0 & 4 & 14 & 39 & 13 & 70 \\
\hline $\begin{array}{l}\text { West Garo } \\
\text { Hills }\end{array}$ & 0 & 11 & 35 & 162 & 42 & 250 \\
\hline $\begin{array}{l}\text { South West } \\
\text { Garo Hills }\end{array}$ & 1 & 7 & 15 & 49 & 3 & 75 \\
\hline $\begin{array}{l}\text { North Garo } \\
\text { Hills }\end{array}$ & 0 & 4 & 13 & 45 & 13 & 75 \\
\hline $\begin{array}{l}\text { South Garo } \\
\text { Hills }\end{array}$ & 0 & 6 & 17 & 33 & 4 & 60 \\
\hline Total & $\begin{array}{c}\mathbf{1} \\
\mathbf{( 0 . 2 \% )}\end{array}$ & $\begin{array}{c}\mathbf{3 2} \\
(\mathbf{6 \%})\end{array}$ & $\begin{array}{c}\mathbf{9 4} \\
(\mathbf{1 7 . 7 \% )}\end{array}$ & $\begin{array}{c}\mathbf{3 2 8} \\
\mathbf{( 6 1 . 9 \% )}\end{array}$ & $\begin{array}{c}\mathbf{7 5} \\
(14.2 \%)\end{array}$ & $\begin{array}{c}\mathbf{5 3 0} \\
(\mathbf{1 0 0 \% )}\end{array}$ \\
\hline
\end{tabular}

Source: field survey

The economic status of farmers in all five districts has been improved. Among the districts, the economic status of the farmers of West Garo hills has improved the most relatively than the remaining four districts as $64.8 \%$ farmers and $16.8 \%$ farmers responded that their economic status is 'improved' and 'significantly improved' respectively (table 9). 
In order to test the variation of average monthly income of farmers from the markets and family economic status improvement across five districts, a One-way Analysis of Variance (ANOVA) is conducted.

\section{Table 12}

\section{ANOVA for average monthly income of farmers from the markets and family economic status improvement across five districts}

\begin{tabular}{|c|c|c|}
\hline Hypotheses & P Value & Acceptance/Rejection \\
\hline $\mathbf{H}_{1}$ & .000 & Rejected \\
\hline $\mathbf{H}_{2}$ & .001 & Rejected \\
\hline
\end{tabular}

From the table 10, it is seen that $\mathrm{H}_{1}$ and $\mathrm{H}_{2}$ are rejected. It indicates that the average monthly income of farmers in the weekly markets in all districts of Garo Hills is not same. It is mainly due to the differences in frequency of participations and volume of commodities sold per day in different districts. It further indicates that the level of improvement of family economic status of farmers of the weekly markets in all districts of Garo Hills is different. It is due to the differences in the average monthly income of farmers across five districts of Garo Hills.

\section{Table 13}

\section{Chi Square test}

\begin{tabular}{|c|c|c|c|}
\hline Hypotheses & P Value & Cramer's V & Acceptance/Rejection \\
\hline $\mathbf{H}_{\mathbf{3}}$ & .089 & .097 & Accepted \\
\hline $\mathbf{H}_{\mathbf{4}}$ & .295 & .094 & Accepted \\
\hline $\mathbf{H}_{5}$ & .838 & .040 & Accepted \\
\hline $\mathbf{H}_{\mathbf{6}}$ & .256 & .100 & Accepted \\
\hline
\end{tabular}

From table 11, it is found that the Pearson Chi-Square value with significance level of $.089(\mathrm{p}>.05)$ not rejecting the null hypothesis $\left(\mathrm{H}_{3}\right)$ leading to the conclusion that there is no association between years of selling commodities in the market and average monthly income from the market, $\chi^{2}(9, \mathrm{n}=530=15.086, \mathrm{p}=.089$, Cramer's $\mathrm{V}=.097)$. Here, the Cramer's V value is .097 , it indicates the effect of years of selling commodities in the market on average monthly income from the market is small (Pallant, 2007:220). Similarly, the Pearson Chi-Square value with significance level of $.295(\mathrm{p}>.05)$ not rejecting the null hypothesis $\left(\mathrm{H}_{4}\right)$ leading to the conclusion that there is no association between years of selling commodities in the market and family economic status improvement, $\chi^{2}(12, \mathrm{n}=530=14.085, \mathrm{p}=$ .295 , Cramer's V =.094). Here, the Cramer's V value is .094, it indicates the effect 
of years of selling commodities in family economic status improvement is small (Pallant, 2007:220). The years of selling commodities in the market has no significant effect on average monthly income from the market $\&$ family economic status improvement. It indicates that average monthly income is not affected by the number of years of selling commodities in the market. The average income is affected by volumes of commodities sold per each market day. Farmers selling more volume of commodities per each market day earn more income that affects the overall monthly average income which is dependent mainly on volume of productions of agriculture and allied products throughout the month. As the average monthly income is not dependent on year of selling commodities in the market, the family economic status improvement is also not affected by the more number of years of participations in the market. Rather, the farmer's economic status is directly linked to the average monthly income.

The Pearson Chi-Square value is .848 (Likelihood Ratio is .875) with significance level of $.838(\mathrm{p}>.05)$ not rejecting the null hypothesis $\left(\mathrm{H}_{5}\right)$ leading to the conclusion that there is no association between frequency of participation in the market and average monthly income, $\chi^{2}(3, \mathrm{n}=530=.848, \mathrm{p}=.838$, Cramer's $\mathrm{V}=$ $.040)$. Here, the Cramer's V value is .040, it indicates the effect of frequency of participation in the market on average monthly income is small (Pallant, 2007:220). The Pearson Chi-Square value is 5.317 (Likelihood Ratio is 5.859) with significance level of $.256(\mathrm{p}>.05)$ not rejecting the null hypothesis $\left(\mathrm{H}_{6}\right)$ leading to the conclusion that there is no association between frequency of participation in the market and family economic status improvement, $\chi^{2}(4, \mathrm{n}=530=5.317, \mathrm{p}=.256$, Cramer's $\mathrm{V}=$ $.100)$. Here, the Cramer's V value is .100, it indicates the effect of frequency of participation in the market on family economic status improvement is medium (Pallant, 2007:220). The frequency of participation in the market has no significant effect on average monthly income and family's economic status improvement of farmers. It indicates that average monthly income is not affected by the frequency of participations of farmers in the market. The average income is affected by volumes of commodities sold per each market day. Farmers producing more commodities and selling these higher volumes of commodities per each market day earn more income that affects the overall monthly average income which is not dependent on frequency of participations. It also indicates that family economic status improvement of farmers is not related with frequency of participations in the markets but rather dependent on average monthly income of farmers.

\section{Conclusion}

Farmers in Garo Hills of Meghalaya participate in the weekly markets as sellers for earning a sustainable income for livelihood. Most of the farmers are participating in the weekly markets seasonally. Most of the farmers in the weekly markets are selling commodities in the market more than 6 years. The average 
monthly income of the farmers is found to be Rs. 2000-5000 and Rs. 5000-8000. With this average monthly income, most of the farmers can manage their family expenditure. Many of the farmers can save after their family expenditure and they use it for children education, medical expenses and assets expansion. However, one third of the farmers can buy new assets as an expansion to the existing. The business of the farmers in the weekly market is growing but it is not profitable throughout the year. Overall, the family economic status is found to be improved and few of them also claimed that their economic status has been significantly improved. The average monthly income of farmers from the markets and improvement of economic status of family are different across five districts of Garo Hills. The years of selling commodities in the market does not have any significant impact on average monthly income from the market and family economic status improvement. Last but not the least, the frequency of participation in the market does not have any significant impact on average monthly income and family economic status improvement of farmers

\section{Implication of the study}

The study is pertinent to understand the economic impact of the weekly markets in the farmers' livelihood. The findings is a valuable contribution to the literature of weekly market study in terms of detailed analysis of economic impacts which is less evidenced in the existing literature. The research findings will be of great help to the policy maker particularly state government and regulatory authority, GHADC which will act as guideline in framing any development related polices and formulating strategies that will optimize the functioning and benefits to all stakeholders of the market. It would also be useful to the consumers as well as farmers in understanding the economic impact in the society at large. Last but not least, it would be beneficial to the individuals who plan to enter into business of weekly market.

\section{Acknowledgment}

The author likes to thank Indian Council of Social Science Research (ICSSR), New Delhi for funding the research. 


\section{Works Cited}

Afsar, K. B. 1993. "Weekly Rural Markets in the North of Iran.”, Social Sciences Letter 6: 172-192.

Barman, M. and Bhatacharjee, A. 2016. "Market Mechanism and Functionaries of Local Haats: An Empirical Study in the Garo Hills Districts of Meghalaya" IBMRD's Journal of Management \& Research 5, no.2: 1-11.

Das, N. and Chattopadhyay, G.P. 2015. "Periodicity and Spatio-Temporal spacing of rural markets of Purba Medinipur Disctrict, West Bengal: An appraisal of the market centre development", Golden Research Thought 4, no.7: 1-12.

Deka, N. and Bhagabati, A. K. 2010. "Periodic Market System in the Rural Areas of Brahmaputra Valley, Assam: The Case of Muktapur Haat.", North Eastern Geographer 36, no.1: 65-79.

Hay, A. M. And Smith, R. H. 1980. "The spatio temporal synchronization of periodic marketplaces: A re-examination." Canadian Geographer/Le Géographe canadien 24, no.2: 149-164.

Ikechukwu, E.E., and Innocent, W.I. 2019. "Roles of Periodic Markets in fostering rural development in Emohua Locak area rivers state, Nigeria." International Journal of Recent Advances in Multidisciplinary Research 6, no.1: 4545-4551.

Kar, A. 2018. The Garos of Meghalaya: Pre-colonial and Colonial Times, Guwahati: DVS Publishers.

Kar, A. 2013. The Garo Frontier Markets in the Nineteenth Century. Tura: D.J. Publication.

Kashyap, P.. and Raut, S. 2010. The Rural Marketing Book: Text and Practice. New Delhi: Biztantra Publications.

Khan, N. 2009. "Role of Periodic Markets in Socio-Economic transformation of rural areas in Ambedkarnagar District (U.P.)." MPhill Thesis submitted to Department of Geography, Aligarh Muslim University.

Khosravi, K. 1979. Research on rural society of Iran. Tehran: The message.

Kio-Lawson, D., Dekor,J. And Chika,C. 2015. "Development of rural periodic markets centres: An effective strategy for rural development in rivers state." Developing Country Studies 5, no.12: 122-134.

Koli, P. A., and Bodhale. A. 2006. Irrigation Development in India. New Delhi: Serials Publications.

Kulkarni, M. S. and Murali, D. 1996. "Study on purchasing practices of consumers of Parbhani Town." Indian Journal of Marketing 26, no.1: 3-7.

Lyson, T., Gillespie, G., and Hilchey, D. 1995. "Farmers' Markets and the local community: Bridging the formal and informal economy." American Journal of Alternative Agriculture 10, no.3: 108-113.

Mukherjee, S. P. 1968. "Commercial Activity and Market Hierarchy in a Part of Eastern Himalaya, Darjeeling." The National Geographical Journal of India 14, no.2: 186-199. 
Pawar, S.K., and Kirulkar, R.S. 2020. "Growth and Distribution of Weekly Market Centers in Kolhapur Disctrict: A Geographical Appraisal." Juni Khyat 10, no.5: 93-99. Perry, D. 2000. "Rural weekly markets and the dynamics of time, space and community in Senegal." The Journal of Modern African Studies 38, no.3: 461-485.

Purkayastha, N. 2019. "Weekly Market: A micro level study on Byrnihat market in Ri Bhoi district of Meghalaya." EPRA International Journal of Multidisciplinary Research 5, no.12: 123-130.

Rao, I. J. And Rajagopal, K. R. 2001. "A study of strain-induced crystallization of polymer." International Journal of Solids and Structures 38, no. 6: 1149-1167.

Roy, A. N. and Basu, G. 2010. "Development of newer products with spun wrapped Jute yarns." Indian Journal of Natural Products and Resources 1, no.2 pp: 11-16.

Sathyanarayana S. 2011. "Trends in the marketing of FMCGs in Karnataka state." Dharana Bhavan's International Journal of Business 5, no.2: 61-73.

Sayulu, K. and Ramana Reddy, V. V. 1996. "Socio-economic influences on rural consumer behaviour-An empirical study." Management Researches 3: 41-51.

Scott, E. P. 1972. "The spatial structure of rural northern Nigeria: farmers, periodic markets, and villages." Economic Geography 48, no.3: 316-332.

Sinha, P. K., and Pradhan, P. K. 2009. "Local Market and Environment: A Case Study of Goilkera Block in West Singhbhum District in Jharkhand." Jharkhand Journal of Social Development.2, no.1: 150-155.

Thakur, R. N. 1997. Periodic Markets: Implications for Rural Development. New Delhi: Rajesh Publications.

Wanmali, S. 1987. Periodic Marketing and Rural Development in India: Contributions to Indian Geography. New Delhi: Heritage Publishers.

Velayudhan, S. K. 2007. Rural Marketing: Targeting the Non-Urban Consumer. 2nd ed. New Delhi: Response Books.

\author{
Dr. Sunildro L.S. Akoijam \\ Department of Management \\ North Eastern Hill University (NEHU), Tura Campus \\ Tura-794002, Meghalaya, India \\ Email: sunil.mba.amity@gmail.com; drsunildroakoijam@gmail.com
}

